\title{
К.В. Шкурупій
}

Харківський національний університет міського господарства імені О.М. Бекетова, Украӥна

\section{ПРОБЛЕМИ ВЕДЕННЯ МАЛОГО ТА СЕРЕДНЬОГО БІЗНЕСУ В УКРАЇНІ. КЛЮЧ ДО ВИРІШЕННЯ ПРОБЛЕМИ БЕЗРОБІТТЯ}

У статті розглянуто можливі проблеми при веденні підприємницької діяльності в наші дні, важливість підприємств для економіки держави, вплив ведення бізнесу на неї. Були розглянуті такі проблеми: недостатньо кваліфікований та обізнаний персонал, недосконала державна регуляторна політика щьодо суб 'єктів підприємництва, високі ставки оподаткування та головна проблема - нестача фінансових ресурсів. Наведено ключ до вирішення проблеми безробіття в країні, який також вирішує низку соціальних проблем.

Ключові слова: проблеми ведення бізнесу, фінансові ресурси, безробіття, соціальні проблеми, зоомісто.

\section{Постановка проблеми}

На сьогодні підприємницька діяльність дуже важлива для економіки України. Малі підприємства забезпечують стійкість та розвиток економічної системи, задовольняють потреби споживачів у різних сферах діяльності, а найважливіше - вирішують актуальну проблему безробіття в країні.

На жаль, займаючись підприємницькою діяльністю, можливо зіштовхнутись із низкою проблем, які впливають саме на «життя» конкретного підприємства. Наприклад: нестача фінансових ресурсів, недосконала державна регуляторна політика щодо суб“єктів підприємництва, потреба у новій законодавчій базі, для комфортного ведення підприємницької діяльності та високі ставки оподаткування. Також, впливають і такі фактори, як: недостатньо обізнані підприємці ( керівники, працівники та ін.), тобто, нестача знань при веденні власної справи.

\section{Аналіз останніх досліджень}

Проблема ведення бізнесу була актуальною завжди, ще 3 античної епохи. У ті часи підприємницька ініціатива виявлялася в успішній колонізації прибережної смуги Чорного й Азовського морів, у контактах із сусідніми племенами.. Проблеми еволюціонували спільно 3 метою, методами та видами підприємницької діяльності. Багато економістів, політиків та науковців аналізували проблеми та перспективи розвитку малого і середнього бізнесу в Україні на даний час, серед яких і О.М. Кашуба, I.М. Манаєнко, Ю.Я. Візняк, А.М. Безус, Г.С. Швець, О.Я. Сідун, Г.М. Кампо, 3.С. Варналій $[1,2,3 .$.$] та ін. Не зважаючи на$ кількість проведених досліджень, багато проблемних питань залишаються невирішеними.

\section{Формулювання мети статті}

Метою дослідження $\epsilon$ виявлення проблем ведення, розвитку та існування малого і середнього бізнесу, визначення шляхів вирішення проблеми безробіття.

\section{Виклад основного матеріалу}

Підприємництво - це вільна, ініціативна діяльність людей у різних сферах виробництва, що здійснюється на власний страх і ризик, 3 метою одержання прибутку. Світовий досвід доводить, що сьогодні без розвитку різних форм підприємницької діяльності подальший розвиток економіки неможливий. В Україні діють ряд нормативних актів, які заклали підгрунтя для формування і розвитку підприємництва. Для забезпечення розвитку вільного підприємництва в Україні законодавчо визнано права, обов'язки та відповідальність суб“єктів підприємницької діяльності, яка зорієнтована на ефективне господарювання[3]. Але, на жаль, законодавча база вже достатньо застаріла, для більш зручного ведення підприємницької діяльності хотілось би відкоригувати іiі та створити єдиний блок законів, правил, що давав би відповіді на можливі питання при їх виникненні.

Підприємництво несумісне 3 господарською некомпетентністю, втратами, безвідповідальністю, невиконанням прийнятих зобов'язань і договорів 3 контрагентами. [3]

Малий та середній бізнес здійснюється шляхом створення розгалуженої системи малих підприємств. До малих відносять такі підприємства:

- Промисловість і будівництво - число працюючих до 200 чоловік;

- Наука та наукове обслуговування - число працюючих до 100 чоловік; 
- В інших галузях виробничої сфери (крім роздрібної торгівлі) - число працюючих до 50 чоловік;

- Роздрібна торгівля - число працюючих до 15 чоловік.

Малі підприємства - досить популярна i актуальна форма господарювання. В Україні сектор малих та середніх підприємств охоплює 99,9\% від загальної кількості (1,97 млн.) підприємств та фізичних осіб-підприємців, зареєстрованих станом на 2015 рік. Згідно даним Державної служби статистики України кількість суб“єктів розподілилась таким чином:

Таблиця 1

Кількість суб“єктів господарювання з розподілом за їх розміром[4]

\begin{tabular}{|l|l|l|l|l|l|}
\hline Рік & Разом & Великі & Середні & Малі & Мікро \\
\hline 2010 & 2183928 & 586 & 21338 & 88316 & 2093668 \\
\hline 2011 & 1701620 & 659 & 21059 & 71013 & 1608919 \\
\hline 2012 & 1600127 & 698 & 20550 & 61103 & 1510776 \\
\hline 2013 & 1722070 & 659 & 19210 & 65021 & 1637180 \\
\hline 2014 & 1932161 & 497 & 16618 & 55159 & 1159887 \\
\hline 2015 & 1974318 & 423 & 15510 & 47555 & 1910830 \\
\hline
\end{tabular}

Однак, немає інформації станом на 2019 рік, але ми можемо спостерігати тенденцію зменшення кількості суб'єктів господарювання.. Таким чином, кількість суб'єктів у 2010 році значно більша ніж кількість суб‘єктів у 2015 році. Це пов“язано з тим, що для існування малих та середніх підприємств існують деякі перепони, актуальні проблеми. Вони можуть взагалі зробити підприємство неприбутковим або «знищити» його назавжди.

На мій погляд, найважливішою проблемою є нестача фінансових ресурсів. 32014 року економіка України знаходиться у досить важкому стані, у зв'язку з цим дуже багато підприємств припинило своє функціонування, деякі мешканці залишились без місця роботи або 3 мінімальною заробітною платнею. Наприклад: підприємство не має фінансових ресурсів для забезпечення ефективного виробничого процесу(не має змоги закупити сировину, матеріали належної якості та ін.). Робітники, що працювали на цьому підприємстві змушені покинути підприємство і залишитись без фінансових ресурсів, тепер вони не мають змогу придбати якісні товари, що, наприклад, виробляє інше підприємство і виходить кругообіг «зачинених» підприємств.

Рівень безробіття в Україні з 2000 по 2017 рр. , тис.[4]

\begin{tabular}{|l|l|l|l|l|}
\hline Рік & $\begin{array}{l}\text { Всього } \\
\text { населення }\end{array}$ & $\begin{array}{l}\text { Економічно } \\
\text { активне } \\
\text { населення }\end{array}$ & $\begin{array}{l}\text { Безробітне } \\
\text { населення }\end{array}$ & $\begin{array}{l}\text { Рівень } \\
\text { безробіття }\end{array}$ \\
\hline 2000 & 48923,2 & 21150,7 & 2630,0 & $12,4 \%$ \\
\hline 2001 & 48457,1 & 20193,6 & 2440,3 & $11,7 \%$ \\
\hline 2002 & 48003,5 & 20669,5 & 2128,6 & $10,3 \%$ \\
\hline 2003 & 47622,4 & 20618,1 & 1994,0 & $9,7 \%$ \\
\hline 2004 & 47280,8 & 20582,5 & 1888,2 & $9,2 \%$ \\
\hline 2005 & 46929,5 & 20481,7 & 1595,2 & $7,8 \%$ \\
\hline 2006 & 46646,0 & 20545,9 & 1513,7 & $7,4 \%$ \\
\hline 2007 & 46372,7 & 20606,2 & 1416,7 & $6,9 \%$ \\
\hline 2008 & 46143,7 & 20675,7 & 1424,0 & $6,9 \%$ \\
\hline 2009 & 45962,9 & 20321,6 & 1956,6 & $9,6 \%$ \\
\hline 2010 & 45778,5 & 20220,7 & 1784,2 & $8,8 \%$ \\
\hline 2011 & 45633,6 & 20247,9 & 1731,7 & $8,6 \%$ \\
\hline 2012 & 45553,0 & 20393,5 & 1656,6 & $8,1 \%$ \\
\hline 2013 & 45426,2 & 20478,2 & 1576,4 & $7,7 \%$ \\
\hline 2014 & 42928,9 & 19035,2 & 1847,1 & $9,7 \%$ \\
\hline 2015 & 42760,5 & 17393.0 & 1654,0 & $9,5 \%$ \\
\hline 2016 & 42584,5 & 17303,6 & 1677,5 & $9,7 \%$ \\
\hline 2017 & 42316,4 & 17193,2 & 1697,3 & $9,9 \%$ \\
\hline
\end{tabular}

- $\quad$ з 2014 р. без урахування окупованих територій (Криму, Севастополя, частини Донбасу) 
На жаль, повних даних за 2018 рік ще не оприлюднено. Аналізуючи ті роки, що представлені, необхідно відзначити, що 32014 року рівень безробіття значно підвищився, навіть, не зважаючи на те, що не враховані люди, що проживають на окупованій території. Кількість людей стала значно меншою, а рівень безробіття - вище.

Звичайно, у цій ситуації потрібно не сидіти склавши руки, а шукати розв'язок цієї проблеми, якою є причина іiі виникнення. Багато глобальних проблем пов'язані із тим, що не має ладу у суспільстві, стабільності та наявність маленьких проблем, які накопичуються та створюють одну велику і розгалужений лад у суспільстві. Отже, для того, щоб роз'вязати великі проблеми, потрібно розібратись із малими.

На сьогодні, у Харкові та інших великих містах України $\epsilon$ актуальною проблема безпритульних тварин. Кожен день ми бачимо велику кількість самотніх тварин, у яких було дуже жахливе минуле, але ми можемо змінити їх майбутнє. Для того, щоб вирішити цю проблему, пропонується організування зооміста, головною метою якого є притулок, котрий буде забезпечуватись завдяки підприємствам на території зооміста. Вони будуть зобов'язані надавати відсоток від місячного прибутку та надавати матеріальну допомогу та їх послуги.

Прикро, що комунальних притулків в Україні небагато, а ті, які є, знаходяться в жалюгідному стані і можуть вмістити в себе малу кількість тварин. У таких притулках дуже часто ми можемо бачити жахливе ставлення до тварин. Також велика частина людей не може відвідувати притулки через невигідне та незручне місце розташування. Це спрямовано перш за все на населення міста Харкова (приблизно 1,5 млн. осіб), а також інших міст України, переважно мегаполісів - Київ, Дніпро, Одеса, Львів.

Зоомісто - вирішення проблем нашого регіону. Створення цього зооміста сприяе значному зменшенню безпритульних тварин, створенню додаткових робочих місць на підприємствах. Головною метою зооміста $\epsilon$ притулок. Але крім притулку будуть функціонувати такі підприємства: ветеринарна клініка, зоомагазин, готель для тварин, хендлінг- зала, центр дресирування тварин, кафе для людини і тварин. Територія зооміста буде постійно оброблятись від усіляких інфекцій та захворювань. Щодо ідеї облаштування такого зооміста, вона може бути перенесена на інші крупні або великі міста України.

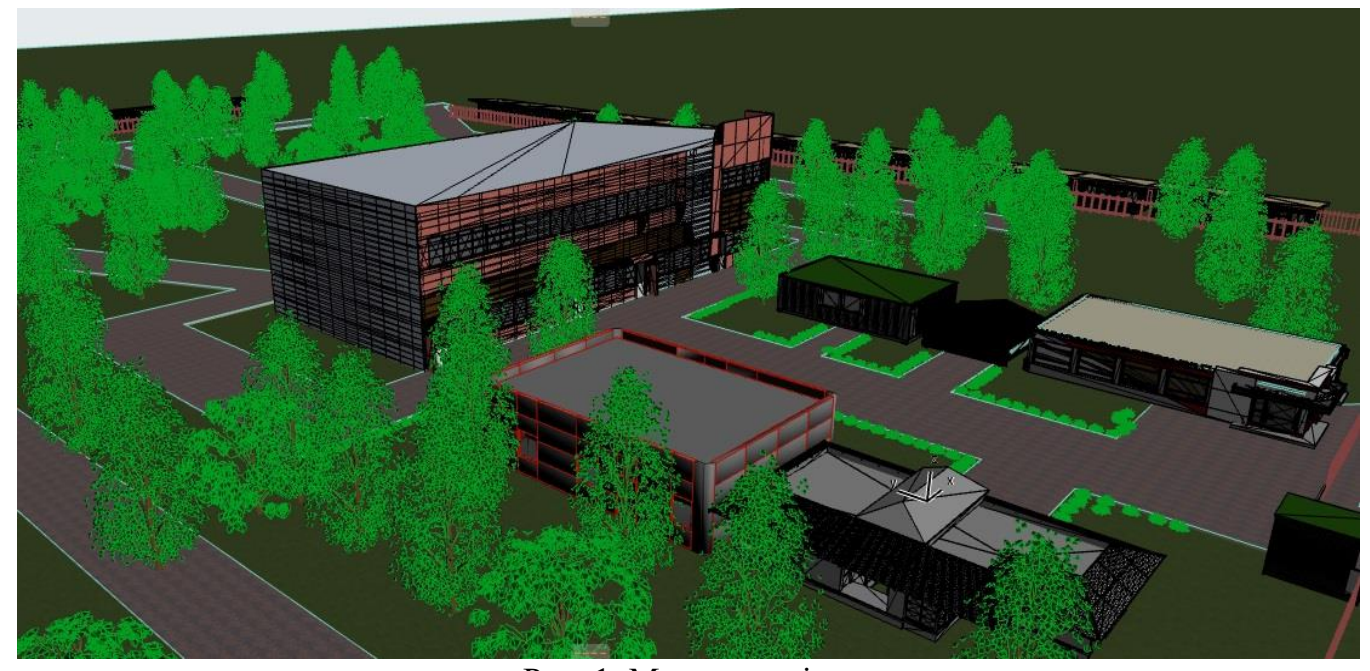

Рис. 1. Макет зооміста

Головною ідеєю $є$ вирішення соціальної проблеми міст України (зокрема Харкова) безпритульних тварини, шляхом відкриття зооміста, де $б$ розмістився притулок для тварин із підприємствами, які б допомагали йому існувати, шляхом забезпечення його матеріальними, фінансовими благами та послугами.

Зоомісто - унікальна ідея. Також, розміщення різноманітних підприємств, що спеціалізуються на наданні зоопослуг в одному місті - це дуже комфортно. На даний момент, ще не існує таких центрів. У таблицях 3, 4 представлено доходи та витрати підприємств.
Дані, представлені на рис. 2 свідчать про те, що за період проведеного аналізу, терміном у 17 місяців, зоомісто перебуває у стадії розвитку. Перші 4 місяці прибутку не варто очікувати, але вже на 5 місяці можна побачити те, що грошовий потік досягає 443000 гривень, а на 17 місяці він становить 10 024400 гривень.

Повертаючись до притулку, через надання 20 \% від ЧД підприємств та їх послуг, він не буде у жахливому стані, а буде охайним, чистим місцем, де б люди змогли прийти і гарно провести час на території зооміста. Всі тварини будуть ситі, здорові та охайні чекати на своїх господарів. 
Інвестиційні та постійні витрати підприємств

\begin{tabular}{|c|c|c|}
\hline Підприсмство & $\begin{array}{c}\text { Інвестиційні } \\
\text { витрати, грн. }\end{array}$ & $\begin{array}{c}\text { Постійні } \\
\text { витрати, грн. }\end{array}$ \\
\hline Ветеринарна клініка & 275400 & 64400 \\
\hline Зоомагазин & 320000 & 57000 \\
\hline Готель для тварин & 226000 & 69000 \\
\hline Хендлінг - зала & 275000 & 59000 \\
\hline Центр дресирування & 268000 & 52000 \\
\hline Кафе & 465000 & 165000 \\
\hline Всього: & 1829400 & 466400 \\
\hline
\end{tabular}

Таблиця 4

Доходи підприємств на місяць

\begin{tabular}{|c|c|}
\hline Підприсмство & Дохід, грн \\
\hline Ветеринарна клініка & $\mathbf{1 8 0 0 0 0}$ \\
\hline Зоомагазин & 415000 \\
\hline Готель для тварин & 75000 \\
\hline Хендлінг - зала & $\mathbf{7 5 0 0 0}$ \\
\hline Центр дресирування & $\mathbf{5 2 5 0 0}$ \\
\hline Кафе & $\mathbf{2 7 0 0 0 0}$ \\
\hline Всього & $\mathbf{1 0 6 7 5 0 0}$ \\
\hline
\end{tabular}

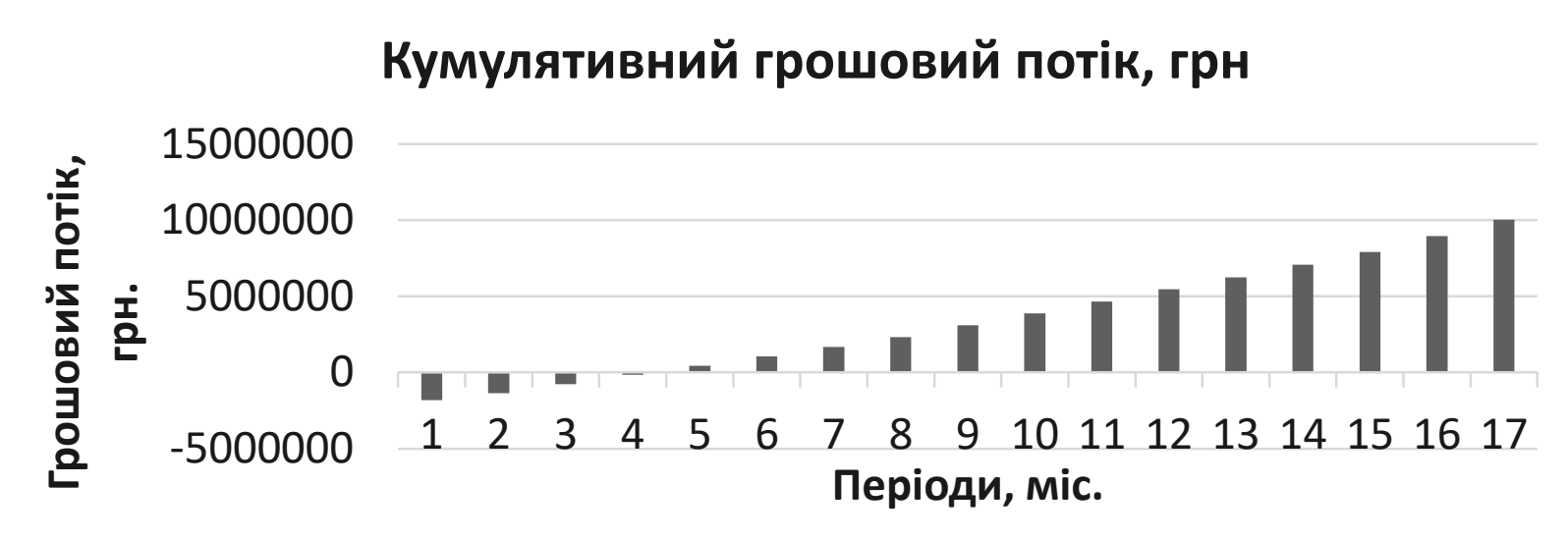

Рис. 2. Кумулятивний грошовий потік зооміста, грн

\section{Висновки}

Здійснення та розвиток підприємницької діяльності - це дуже важливо для нашої країни. Потрібно розвиватись у цій сфері, обмінюватись та набиратись досвіду від інших країн, стимулювати молодь займатись підприємницькою діяльністю. Стосовно ролі держави, то потрібно підтримувати підприємців та підприємства, бо розвиток економіки будь якої держави, а саме - нашої, залежить від функціонування та розвитку підприємств, співпраці 3 іншими країнами та ін. Проблеми ведення бізнесу виникають із маленьких проблем, які поступово, крок за кроком, перетворюються у великі, глобальні проблеми. Проблема безробіття - наслідок. Таким чином, вирішення будь-якої соціальної проблеми ключ до успіху та розвитку нашої держави.

\section{Література}

1. Підприємництво в Україні: проблеми і перспективи розвитку [Текст] / О. М. Кашуба // Економіка та держава. - 2015. - № 6. - С. 103-106.

2. Складові інвестиційного забезпечення інновачійного розвитку підприємств електроенергетики [Текст] / I. М. Манаєнко // Економічний вісник Національного технічного університету України "Київський політехнічний iнститут". - 2015. - № 12. - C. 434-441.

3. Візняк, Ю.Я. Діагностика бізнес-середовища підприємства $i$ роль неурядових організачій щзодо 
запобігання та протидії корупиії у сфері оподаткування [Текст] / Ю.Я. Візняк // Економіка підприємництва. - 2016. - No 1. - C. 235-240.

4. Безус, А.М. Розвиток підприємств малого бізнесу в Украӥні [Текст] / А.М. Безус // Проблеми розвитку економіки. - 2016. - o 3(99). - C. 7-17.

5. Основи економічної теорії [Текст]: Навчальний посібник /М. О. Ажнюк, О. С. Передрій. - К.: Знання, 2008. - 365 с.

6. Відомості Державної служби статистики Украӥни [Електронний ресурс] - Режим доступу: http://www.ukrstat.gov.ua.

7. Швець, Г. С. Сучасне бізнес-середовище малого та середнього підприємництва в Украӥні [Текст] / Г.С. Швеичь // Вісник Приазовського державного технічного університету. - 2017. - Bun. 34. - C. 31-39.

8. Кампо, Г. М. Управління розвитком малого бізнесу регіону [Текст]: автореф. дис. на здобуття наук. ступеня канд. екон. наук: спец. 08.00.05 / Г. М. Кампо; Ужгородський національний університет. - Ужгород, 2009. $-21 c$.

9. Сідун, О. Я. Регіональні механізми розвитку малого підприємництва (на матеріалах Закарпатської області) [Текст]: автореф. дис. на здобуття наук. ступеня канд. екон. наук: спец. 08.06.01 / О. Я. Сідун. - Ужгород, 2004. -22 с.;

10. Варналій, 3. С. Мале підприємництво: основи теорії $i$ практики [Текст] / 3.С. Варналій. - 4-те вид. - К.: Т-во «Знання», КОО, 2008. - 302 c.

\section{References}

1. Kashuba, O.M. (2015) Entrepreneurship in Ukraine: Problems and Prospects for Development. Economy and the State, 6, 103-106.

2. Manayenko, I.M. (2015) Components of investment support for innovation development of electric power companies. Economic Bulletin of the National Technical University of Ukraine "Kyiv Polytechnic Institute", 12, 434-441.
3. Vysnyak, Yu.Ya. (2016) Diagnostics of the business environment of the enterprise and the role of non-governmental organizations in preventing and combating corruption in the field of taxation. Business Economics, 1, 235-240 .

4. Bezus, AM (2016) Development of Small Business Enterprises in Ukraine. Problems of economic development, 3 (99), 7-17.

5. Ajnyuk, M.O., Derryi, O.S. (2008) Fundamentals of Economic Theory: Textbook - K .: Knowledge, 365.

6. Information from the State Statistics Service of Ukraine (n.d.) Retrieved from http://www.ukrstat.gov.ua.

7. Shvets, GS (2017) Modern Business Environment of Small and Medium Enterprises in Ukraine. Bulletin of the Priazovsky State Technical University, 34, 31-39.

8. Campo, G. M. (2009) Management of the development of small business in the region: author's abstract. dis for the sciences. Degree Candidate econ Sciences: special 08.00.05. Uzhgorod National University, 21.

9. Sidoun, O. Ya. (2004) Regional mechanisms of development of small business (on materials of Transcarpathian region): author's abstract. dis for the sciences. Degree Candidate econ Sciences: special 08/06/01. Uzhgorod, 22.

10. Varnalius, Z.S. (2008) Small Business: Fundamentals of Theory and Practice - 4th kind. - K .: T-"Knowledge", KOU, 302.

Рецензент: доктор економічних наук, професор O. В. Димченко, Харківський національний університет міського господарства імені О.М. Бекетова, Україна
Автор: ШКУРУПІЙ Катерина Вікторівна студентка кафедри економіки підприємств, бізнес- адміністрування та регіонального розвитку, факультет економіки і підприємництва Харківський національний університет міського господарства імені О. М. Бекетова E-mail-shkurupiy63@gmail.com

\section{PROBLEMS OF DOING SMALL AND MEDIUM-SIZED BUSINESS IN UKRAINE IN THE CONTEXT OF SOLVING THE UNEMPLOYMENT PROBLEM \\ K.V. Shkurupiy}

O.M. Beketov National University of Urban Economy in Kharkiv, Ukraine

The article discusses possible problems in doing business today, the importance of enterprises for the state economy and the impact of doing business in Ukraine. The following issues were considered: insufficiently skilled and knowledgeable staff, imperfect state regulatory policy for business entities, high tax rates and the main problem-the lack of financial resources. Proposed ways which will help to solve the unemployment problem in Ukraine, including number of social problems. Today in the city of Kharkiv and other large cities of Ukraine, the problem of homeless animals is a topical issue. In order to solve this problem, proposed to organize a zoo-city, the main idea of which is the shelter, which will be provided through enterprises on the zoo-city. They will be obliged to provide a percentage of the monthly income and provide material assistance and their services. Creation of this zoo-city promotes a significant reduction of homeless animals, creation of additional workplaces at the enterprises. Solving such social problems as: homeless animals, unemployment through the zoo-center, as well as the active dissemination of the public spirit will significantly improve the city and will stimulate the country's further development. We need to support entrepreneurs and enterprises, because the development of the economy of any state, namely ours, depends on the functioning and development of enterprises, cooperation with other countries, etc. Problems of doing business arise from small problems that gradually, step by step, turn into big and global problems. The problem of unemployment is a consequence. World experience proves that today, without the development of various forms of entrepreneurial activity and the functioning of enterprises, further development of the economy is impossible. Thus, the solution of any social problem is the key to the success and development of our state.

Keywords: problems of doing business, financial resources, unemployment, social problems, zoo-city. 